\title{
THE COMPREHENSION OF DEICTIC TERMS IN NORMAL AND LANGUAGE IMPAIRED CHILDREN
}

\author{
MICHELLE MENTIS, B.A. (SP. \& H. TH.) (WTTWATERSRAND) \\ Department Speech Therapy and Audiology, Groote Schuur Hospital, Cape Town
}

\begin{abstract}
SUMMARY
This study examined the comprehension of four pairs of deictic terms in a group of language impaired children and compared their interpretation of these terms with those of non-language impaired children of the same age range. Each group was comprised of ten subjects within the age range of 9,6 to 10,6 years. Two tasks were administered, one to assess the comprehension of the terms here, there, this, and that and the other to assess the comprehension of the terms, come, go, bring and take. The results showed that while the non-language impaired subjects comprehended the full deictic contrast between the pairs of terms tested, the language impaired group did not. A qualitative analysis of the data revealed that the language impaired subjects appeared to follow the same developmental sequence as normal children in their acquisition of these terms and responded by using the same strategies that younger non-language impaired children use at equivalent stages of development. Furthermore, the language impaired subjects appeared to comprehend the deictic terms in a predictable order based on their relative semantic complexity.
\end{abstract}

\section{OPSOMMING}

Hierdie studie ondersoek die verstaanbaarheid van vier pare diektiese terme in 'n groep taalversteurde kinders en vergelyk hulle interpretasie van hierdie terme met dié van normale kinders in dieselfde ouderdomsgroep. Elke groep is saamgestel uit tien proefpersone in die ouderdomsgroep van 9,6 tot 10,6 jaar. Twee take is aan hulle gestel, om hulle begrip van die terme: hier, daar, hierdie en daardie en kom, gaan, bring en neem/vat vas te stel. In die eerste taak is van die kinders verwag om volgens instruksie een van ' $n$ diere paar te beweeg, en in die tweede, moes hulle die "spreker" en die "aangespreekte" uitken. Resultate het aangetoon dat terwyl die normale kinders die diektiese kontras tussen die paar terme wat getoets is, verstaan, die taalversteurde kinders, dit nie begryp het nie. 'n Kwalitatiewe analise van die data het aangedui dat die taalversteurde kinders skynbaar dieselfde ontwikkelings-volgorde, as dié van nomnale kinders in die aanleer van hierdie terme volg, en dat van dieselfde strategieë as die van jonger normale kinders met 'n ooreenstemmende ontwikkelingsvlak, gebruikgemaak is. Dit het geblyk dat die taalversteurde kinders die diektiese terme in 'n voorspelbare volgorde, gebaseer op die terme se relatiewe semantiese kompleksiteit, verstaan.

Deixis has been defined as "the term for linguistic devices that anchor the utterance to the communicative setting in which it occurs". ${ }^{14}$ Deictic terms are used to point out a particular object, position or direction in relation to the speaker, and can only be interpreted in the actual context of such utterances, with reference to the specific characteristics of the spatio-temporal conditions which exist at the moment of utterance. ${ }^{11}$ In fact, Ingram, as cited by Rees, ${ }^{14}$ states that "Deictic features handle the fact that language is used to communicate between speakers and hearers". As such, it is intimately bound to the area of pragmatics which occupies the interface between linguistic, cognitive and social development. ${ }^{14}$ 
Traditionally deixis has been divided into three categories: time, person and place deixis. Place deixis, the concern of the present study comprises devices for expressing the speaker's view of his position relative to the listener and other surroundings. ${ }^{14}$ Examples of these are the locational adverbs here and there, the demonstrative adjectives this and that, and the verbs come, go, bring and take.

There are three factors that contribute to the underlying complexity of deictic terms. ${ }^{4}, 6,13$ These are that: deictic terms all have a point of reference; they involve a shifting reference; and they have shifting boundaries.

The normal point of reference for deictic terms is the speaker, e.g. here locates the place near the speaker as opposed to the place further away (there) and this locates an object near the speaker and that an object away from the speaker. Here and this are thus proximal with respect to the point of reference, while there and that are nonproximal. From this it can be seen that the perception of deictic contrasts involves the mastery of two principles: the speaker principle which indicates that the speaker is the point of reference; and the distance principle which indicates that each pair of terms contrasts on the distance dimension. ${ }^{6}$

The fact that all deictic expressions involve a shifting reference indicates that the meaning of these terms varies depending on who is speaking at that particular time. It is because all deictic terms involve shifting reference that the speaker principle is difficult to master. ${ }^{6}$ However, the reference of here and there not only shifts with every change of speaker, but in addition to this shifts with every change of position of each speaker. Here locates the speaker's place which may or may not include the listener's place. If it does not, then the location of there also shifts with every change of listener. Thus there shifts reference even more than here. The more shifting a term involves, the harder it is for the child to master. Thus as the non-proximal terms (there and that) shift more than the proximal ones, they are more difficult to acquire. ${ }^{4,6,7}$ Furthermore, it has been suggested that the difference in the amount of shifting between the terms predisposes children to treat both terms of a pair as if they were proximal. ${ }^{6}$

The distance principle may be considered to be difficult to acquire because of the shifting boundaries of deictic terms. This refers to the fact that the physical space located by the word here differs according to the context in which it is used. Thus here may be used to indicate the precise spot on the floor where the speaker is standing (here where I am) or the room he is in (here in the study). The context of discourse thus determines the distance that will be referred to.

The foregoing discussion illustrates the fact that in order for spatial deictic terms to be understood, the hearer must not only know the speaker's position in space and his point of view, but must also understand the context of the utterance. Furthermore, he needs to know whether his own position and point of view differs from that of 
the speaker. The differing levels of complexity for spatial deictic terms are represented in Table I.

TABLE I:

Degree of Complexity of Spatial Deictic Terms

\begin{tabular}{|l|l|}
\hline DEICTIC TERMS & \multicolumn{1}{|c|}{ DEGREE OF COMPLEXITY } \\
\hline 1. here - there & speaker and place \\
\hline 2. this - that & speaker and place and object \\
\hline 3. come - go & speaker and place and object and movement \\
\hline 4. bring - take & speaker and place and object and movement and cause \\
\hline
\end{tabular}

It has been suggested that the true deictic contrast between pairs of deictic terms is acquired through a process in which semantic features are added to the words until the adult meaning is attained. ${ }^{16}$ This is in accord with Clark's ${ }^{2,}{ }^{3}, 9$ Semantic Feature Hypothesis (SFH). The acquisition of the deictic verbs come/go and take/bring has been found to be compatible with that predicted on the basis of the relative semantic complexity of the four deictic terms. ${ }^{5}$ However, recent studies indicate that the positive, marked terms here and this are acquired earlier than their negative, unmarked counterparts there and that. ${ }^{6}{ }^{16}$ This result shows that semantic markedness is not applicable to the acquisition of polarity for these terms. This discrepancy has been explained in terms of the fact that children rely on non-linguistic strategies in interpreting the meanings of words and that for the deictic pairs here/there and this/that, the non-linguistic strategy coincided with the negative marked member of the pair, and not, as is usually found, with the positive, unmarked member. ${ }^{5,}, 6,16$

In the course of working out the contrast between deictic terms, children apply different strategies which are the outcome of their changing hypotheses about the meanings of the words. The acquisition of such contrasts has been shown to be characterized by three stages: no contrast, where the children usually use only one of the deictic pair to represent both situations; partial contrast where the other word in the deictic pair is used but only partially or incorrectly contrasted to its counterpart, and then finally the full contrast where the true deictic contrast is perceived. ${ }^{4,5,6}$

To the present writer's knowledge, no research has been undertaken to date on deictic comprehension in language-impaired children. Since, as demonstrated above, deixis appears to be a rich area for characterizing the pragmatic capabilities of the child and for examining the different stages of acquisition, the potential contribution to the study of language impairment is felt to be great. In particular, this aspect may 
be sensitive to the language difficulties of the older child whose problems so often manifest at the level of pragmatics. The present study was thus undertaken to compare the comprehension of deictic expressions in normal and language-impaired children.

\section{METHODOLOGY}

AIM

To examine the comprehension of deictic terms in a group of languageimpaired children and compare their interpretation of these terms with those of non-language impaired children of the same age range. For the purposes of this study the following contrasting pairs of place deixis were chosen: here - there, which differentiate between the place where the speaker is as opposed to where he is not; this - that, which differentiate between something in the same location of the speaker and something in a different location; come - go, which differentiate between the movement of a person or object towards or away from the place where the speaker is, was or expects to be; and bring - take, which are the causative counterparts of the terms come - go.

\section{HYPOTHESES}

1. Whereas the non-language impaired children will comprehend the full deictic contrast between the pairs of terms, the language impaired children will not.

2. Although the language impaired children will be delayed in their comprehension of these terms, they will employ the same series of strategies in dealing with the tasks as the non-language impaired children.

3. The language impaired children will comprehend these terms in a predictable order based on the semantic complexity of the terms and according to acquisition in non-language impaired children. $5,6,16$

\section{SUBJECTS}

Two groups of subjects (Ss) comprising an experimental (E) group of ten language impaired children and a control (C) group of ten non-language impaired children were selected. On the basis of a pilot study, the age range was between 9,6 and 10,6 years.

All Ss came from white, English-speaking, middle class South African homes. They were required to be of average intelligence and to have hearing within normal limits.

Due to the visual nature of the task, Ss were also required to have no visual spatial problems as assessed by the occupational therapists attached to the remedial schools.

TASKS

Task 1

To assess the comprehension of the deictic terms herelthere and this/that. (Based on a study designed by Clark and Sengul ${ }^{6}$ ). Testing 
was carried out under two conditions: (a) with the tester and child seated at a table beside each other (same perspective) and (b) with the tester and child seated at a table opposite each other (different perspective).

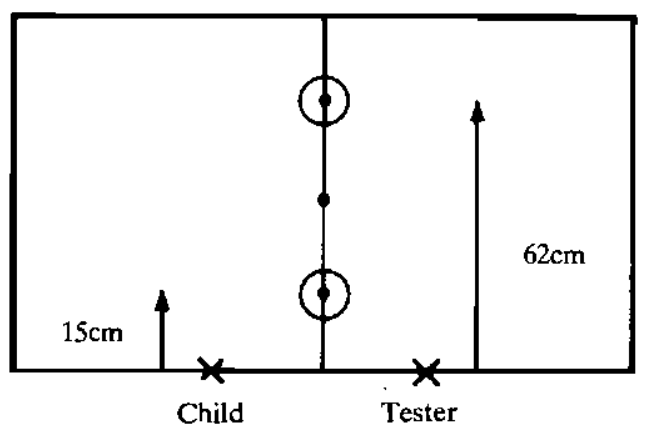

Figure 1a: Testing Situation used for Task 1: Condition a

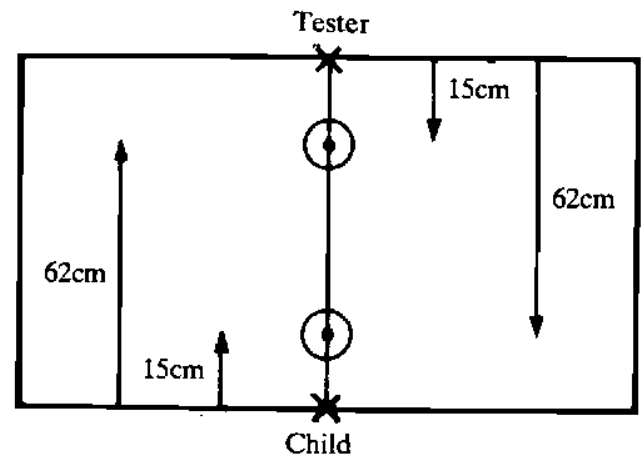

Figure 1b: Testing Situation used for Task 1: Condition b

One pair of identical toy animals was placed on the table for each instruction.

The task was introduced as a game in which the $S$ had to decide which of two toy animals moved. On each trial the tester placed a pair of animals on the table, named them alternately and asked the child to look at them both. Instructions such as "make the dog over there turn around" or "make this chicken hop" were then given ánd the S was required to respond by making one of the animals move. There were eight practice trials, one for each combination of word and condition followed by thirty-two test trials.

\section{Task 2}

To assess the comprehension of the deictic terms comelgo and bring/take. (Based on a study designed by Clark and Garnica ${ }^{5}$ ). Each 
child was seated next to the tester at the table with a display board on which was placed a model house, pool, barn and garden. (These models will be referred to as goals.) For each instruction, one set of three animals was arranged on the board as if at the points of a roughly equilateral triangle with one point inside one of the goals and the other two outside as shown in Figure 2. The three animals on the points all faced each other. With bring and take the appropriate animal carried a small object. The task was introduced as a game in which various animals lived on a farm and in which all the animals could speak to each other. Each child had to tell the tester which animal was talking or to whom a particular animal was talking - i.e. identify either the speaker or addressee. Each of the four deictic verbs come, go, bring and take were used in each of four situations. In two of the situations the child had to identify the speaker (Sp. 1 and Sp. 2) and in the other two, had to identify the addressee (Ad. 1 and Ad. 2). On each trial the tester placed the three animals in their appropriate position, named them and the goal and then gave the child instructions such as "which animal can say to the lion: "Come into the house?", or 'The pig says: "Can I come into the barn?"' Which animal is he talking to? The child was then required to identify either the speaker or the addressee.

There were four practice trials, one for each verb in each of the four situations followed by forty-eight instructions, twenty-four with come and go and twenty-four with bring and take.

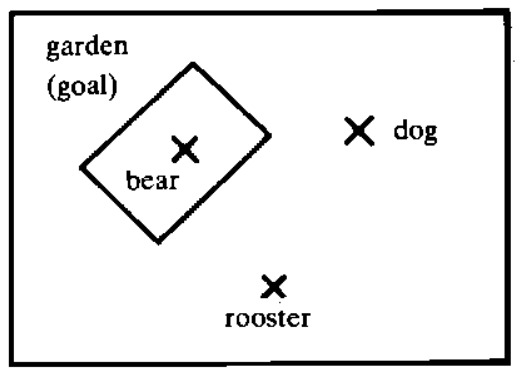

Figure 2. Testing Situation used for Task 2

\section{ANALYSIS OF RESULTS}

For Task 1 each S's responses were scored as correct or incorrect according to which animal they moved. For Task 2 each S's responses were scored as correct or incorrect according to the choice of animal as speaker or addressee. Results of both tasks were analysed on an overall basis as well as on an individual task basis. The data were subjected to both statistical and qualitative analysis.

\section{RESULTS AND DISCUSSION}

\section{TASK 1}

A summary of mean scores and percentages of semantically correct responses produced by each group can be seen in Table II. 
TABLE II Mean Scores and Percentages of Semantically correct responses produced by each group on Task 1 .

\begin{tabular}{|c|c|c|c|c|c|c|c|c|}
\hline \multirow{2}{*}{ DEICTIC TERM } & \multicolumn{3}{c}{ SPEAKER BESIDE } & \multicolumn{2}{c|}{ SPEAKER OPPOSITE } \\
\cline { 4 - 9 } & \multicolumn{2}{|c}{$\mathrm{C}$} & \multicolumn{2}{c|}{$\mathrm{E}$} & \multicolumn{2}{c|}{ C } & \multicolumn{2}{c|}{ E } \\
\hline & $\overline{\mathrm{X}}$ & $\%$ & $\overline{\mathrm{X}}$ & $\%$ & $\overline{\mathrm{X}}$ & $\%$ & $\mathrm{X}$ & $\%$ \\
\hline here & 4 & 100 & 3,8 & 95 & 4 & 100 & 1,4 & 35 \\
\hline there & 4 & 100 & 2,2 & 55 & 4 & 100 & 2,5 & 62,5 \\
\hline here there & 8 & 100 & 6 & 75 & 8 & 100 & 3,9 & 48,75 \\
\hline this & 4 & 100 & 3,9 & 97,5 & 3,7 & 92,5 & 1,1 & 27,5 \\
\hline that & 4 & 100 & 1,8 & 45 & 4 & 100 & 2,8 & 70 \\
\hline this that & 8 & 100 & 5,7 & 71,25 & 7,7 & 96,25 & 3,9 & 48,75 \\
\hline
\end{tabular}

TABLE III Mean Scores of Semantically correct responses to proximal and distal terms in each of the two situations (Task 1)

\begin{tabular}{|c|c|c|}
\hline $\begin{array}{c}\text { DEICTIC } \\
\text { TERM }\end{array}$ & $\begin{array}{c}\text { SPEAKER } \\
\text { BESIDE }\end{array}$ & $\begin{array}{c}\text { SPEAKER } \\
\text { OPPOSITE }\end{array}$ \\
\hline here - this & 7,7 & 2,5 \\
\hline there-that & 3,3 & 5,3 \\
\hline
\end{tabular}

TABLE IV: Number of Ss that fell into each category for each pair of terms (Task 1)

\begin{tabular}{|c|c|c|c|c|c|c|}
\hline & \multicolumn{3}{|c|}{ Here - There } & \multicolumn{3}{c|}{ This - That } \\
\hline & $\begin{array}{c}\text { No } \\
\text { Contrast }\end{array}$ & $\begin{array}{c}\text { Partial } \\
\text { Contrast }\end{array}$ & $\begin{array}{c}\text { Full } \\
\text { Contrast }\end{array}$ & $\begin{array}{c}\text { No } \\
\text { Contrast }\end{array}$ & $\begin{array}{c}\text { Partial } \\
\text { Contrast }\end{array}$ & $\begin{array}{c}\text { Full } \\
\text { Contrast }\end{array}$ \\
\hline E & 4 & 4 & 1 & 4 & 4 & 1 \\
\hline C & 0 & 0 & 10 & 0 & 0, & 10 \\
\hline
\end{tabular}

All Ss in Group $C$ perceived the full deictic contrast between both pairs of terms in both situations, and were thus considered to have mastered both the speaker and the distance principles. These results support the first aspect of $\mathrm{H}_{1}$.

Ss in Group E did not perceive the full deictic contrast between the pairs of terms tested in either situation. These results fully supported the second aspect of $\mathrm{H}_{1}$. The percentage of correct responses varied according to the specific term used and the situation in which it was 
used. This was in accord with the prediction $\left(\mathrm{H}_{3}\right)$ that the Ss woul comprehend the full meaning of each term in a predictable order based on the semantic complexity of the terms and the order of acquisition in non-language impaired children. Thus in the "speaker beside" situation Group E Ss obtained a higher mean score for the linguistically simpler deictic pair here-there than for the pair this-that $(\mathrm{T}=8 ; \mathrm{n}=$ $10 ; \mathrm{p}<0,025)$ and for the linguistically simpler proximal terms (there \& that $)(\mathrm{T}=0 ; \mathrm{N}=10 ; \mathrm{p}<0,005)$. However, in the "speaker opposite" situation Ss obtained similar scores for both pairs of deictic terms ( $\mathrm{T}=10 ; \mathrm{N}=10$; not significant) and as can be seen in Table II were more often correct for the non-proximal terms $(\mathrm{T}=6 ; \mathrm{N}=10 ; \mathrm{p}$ $<0,025)$. A reason for the $S s$ obtaining similar scores for both pairs of deictic terms may be that the task in this situation was a more complex one as it required full perception of the deictic contrast. Correct responses to both pairs of terms was dependent on the Ss' ability to take the speaker's perspective and was thus dependent on mastery of the speaker principle. With respect to the Ss being more often correct on the non-proximal terms, it was felt that this was not a result of their comprehending the true meaning of the terms there and that but rather a result of their overextended use of the proximal terms.

Thus if the Ss responded to both terms as if they meant closer to the child, then in the speaker opposite situation, the Ss would respond incorrectly to the proximal terms but correctly to the non-proximal ones. This is then in accord with the hypothesis $\left(\mathrm{H}_{3}\right)$ that the semantically simpler terms are acquired before their more complex counterparts.

This phenomenon of overextension occurs when the meaning of one member of a pair of terms is extended to cover both words, and has been frequently cited as occurring during the initial stages of semantic development of relational terms and adjective pairs. ${ }^{1,15}$ In the present study the phenomenon of overextension was evident in the responses of all $\mathrm{Ss}$ in Group $\mathrm{E}$ at the most primitive level of comprehension of deictic terms i.e. the no contrast stage. This provides support for $\mathrm{H}_{3}$ as the language impaired Ss were responding in a similar way to that reported in younger non-language impaired children at an equivalent stage of semantic development.

In order to analyse what strategies the Ss were using in responding, the data for each child was studied qualitatively. It was felt that an analysis of the strategies the Ss used in interpreting the words would provide the writer with insight into what hypotheses they had formed about the meaning of the words.

The Ss were calssified into groups on the basis of their individual response patterns in the manner adopted by Clark and Sengul. ${ }^{6}$ They divided the response patterns they obtained into three distinct categories: no contrast, partial contrast and full contrast. Their results indicated that these categories were a function of the ages of their Ss and that they thus represented three ordered stages of acquisition in 
normal children. The Ss in this study were grouped according to these stages.

All Group $C$ subjects were at the full contrast stage whereas only one $S$ in Group E perceived the full deictic contrast. Four of the Ss in Group $E$ were at the no contrast stage, and the other four Ss were at the partial contrast stage. These results support $\mathrm{H}_{1}$ (see Table IV).

A consideration of these patterns and strategies indicated that the Ss followed two basic routes in comprehending the full deictic contrast. Those Ss taking the child-centered route relied on the strategy of choosing the animal nearest themselves and those Ss taking the speaker centered route relied on the strategy of choosing the animal nearest the speaker.

Ss in Group E who appeared to be functioning at the no contrast. and partial contrast stages appeared to use the strategies younger nonlanguage impaired children use in their acquisition of deictic terms. ${ }^{6,16}$ This supports $\mathrm{H}_{2}$ and is consistent with what has been previously reported on the language development of language-impaired children. It has been shown that the behaviour of language-impaired children is rule governed and that although delayed, follows the same development sequence of normal children. ${ }^{10}, 12$ In further support of this prediction, it appeared that nine Ss in Group E were developing comprehension of the full deictic contrast through stages in which semantic features were added in a hierarchical order in accord with Clark's SMH. ${ }^{3}$ This is consistent with what has been reported on the semantic development in non-language impaired children. ${ }^{2,8}$

TASK 2

A summary of mean scores and percentages of correct responses produced by each group can be seen in Table V.

TABle V: Mean Scores and Percentages of Correct responses Produced by each group (Task 2)

\begin{tabular}{|c|c|c|c|c|c|c|c|c|c|c|c|c|}
\hline & \multicolumn{2}{|c|}{ Come } & \multicolumn{2}{|c|}{ Go } & \multicolumn{2}{c|}{ Come Go } & \multicolumn{2}{c|}{ Bring } & \multicolumn{3}{|c|}{ Take } & \multicolumn{3}{|c|}{ Bring Take } \\
\hline & $\overrightarrow{\mathrm{X}}$ & $\%$ & $\overline{\mathrm{X}}$ & $\%$ & $\overline{\mathrm{X}}$ & $\%$ & $\overline{\mathrm{X}}$ & $\%$ & $\overline{\mathrm{x}}$ & $\%$ & $\overline{\mathrm{X}}$ & $\%$ \\
\hline $\mathrm{C}$ & 12 & 100 & 11,2 & 93,3 & 23,2 & 96,6 & 11,5 & 95,8 & 11,9 & 99,2 & 23,4 & 97,5 \\
\hline $\mathrm{E}$ & 10,5 & 87,5 & 3,2 & 26,6 & 13,7 & 57,1 & 10,1 & 84,1 & 4 & 33,3 & 14,1 & 58,75 \\
\hline
\end{tabular}

Whereas all Ss in Group C perceived the full deictic contrast between both pairs of terms, Ss in Group E:did not. These results support $H_{1}$. The percentage of correct responses in Group $\mathrm{E}$ varied according to the specific term used. Although it was postulated that the semantically simpler verb pair come-go would be acquired before its more complex causative counterpart bring-take $\left(\mathrm{H}_{3}\right)$, this view was not supported $(T=21 ; N=10 ;$ not, significant). This result may be 
TABLE VI: Number of Ss that fell into each category for each pair of terms (Task 2)

\begin{tabular}{|c|c|c|c|c|c|c|}
\hline & \multicolumn{3}{|c|}{ Come-Go } & \multicolumn{3}{c|}{ Bring - Take } \\
\hline & $\begin{array}{c}\text { No } \\
\text { Contrast }\end{array}$ & $\begin{array}{c}\text { Partial } \\
\text { Contrast }\end{array}$ & $\begin{array}{c}\text { Full } \\
\text { Contrast }\end{array}$ & $\begin{array}{c}\text { No } \\
\text { Contrast }\end{array}$ & $\begin{array}{c}\text { Partial } \\
\text { Contrast }\end{array}$ & $\begin{array}{c}\text { Full } \\
\text { Contrast }\end{array}$ \\
\hline E & 7 & 2 & 0 & 5 & 4 & 0 \\
\hline C & 0 & 1 & 9 & 0 & 0 & 10 \\
\hline
\end{tabular}

explained in terms of the relative frequencies of use of the deictic verbs in the South African English dialect with the assumption that the more frequent terms are easier to learn because the child will have greater exposure to them. This would be in accordance with the view that external environmental factors influence language acquisition. ${ }^{1,7}$ Ss in Group E made significantly fewer errors on the semantically simpler positive pair come-bring than they did on the semantically more complex negative pair go-take $(\mathrm{T}=4 ; \mathrm{N}=10 ; \mathrm{p}<0,01)$. These results provide support for $\mathrm{H}_{3}$ and are consistent with the claim that positive unmarked members of word pairs are acquired first. ${ }^{9}$ However, this is in contrast to the fact that the proximal pair here and this have been discussed as being linguistically simpler and acquired earlier than the non-proximal pair there and that even although the non-proximal pair represent the positive unmarked terms while the proximal pair represent their negative marked counterparts. ${ }^{6}, 16$ This may be explained in terms of the fact that the Ss were responding on the basis of non-linguistic strategies (for example the proximity and egocentric bias) and these were compatible with the negative marked terms rather than with the positive unmarked ones. In the above instances however, it can be argued that the non-linguistic response biases corresponded with the positive unmarked terms.

The data for each child was classified into the following groups on the basis of their correct responses: no contrast; partial contrast and full contrast. These categories were based on the results obtained by Clark and Garnica $^{5}$ who statistically revealed that the categories were age based and hypothesized that they represented the normal stages of acquisition of these terms.

All Group C Ss fell into the full contrast category for the verbs come and $g o$, while nine of the ten Group C Ss fell into the full contrast category for the verbs bring and take. The other $\mathrm{S}$ fell into the partial contrast category for these verbs. Group $E$ Ss fell into the no contrast and partial contrast categories. For the verbs come and go, seven Ss fell into the no contrast category while two $S$ s fell into the partial contrast category. For the verbs bring and take, five Ss fell into the no contrast category while four Ss fell into the partial contrast category. These results support $\mathrm{H}_{1}$ (see Table VI).

Die Suid-Afrikaanse Tydskrif vir Kommunikasieafwykings, Vol. 28, 1981 
As with Task 1 , Ss in Group E who appeared to be functioning at the no contrast and partial contrast stages appeared to use the strategies younger non-language impaired children use in their acquisition of deictic verbs. ${ }^{5}$ This supports $\mathrm{H}_{2}$.

\section{CONCLUSION}

Results from the statistical and qualitative analysis of the data indicated that the language impaired $S s$ were delayed in their comprehension of deictic terms in comparison with the non-language impaired Ss. These results fully supported the first hypothesis. Group $C$ contained a higher overall mean score for the comprehension of all deictic terms tested $(9,8)$ than did Group $\mathrm{E}(5,82)$. $\left(\mathrm{U}=0 ; \mathrm{N}_{1}=\mathrm{N}_{2}=\right.$ $10 ; \mathrm{p}<0,001)$.

A qualitative analysis of the data revealed that although the language impaired Ss were delayed in their use of these terms, they appeared to follow the same developmental sequence as normal children, passing through the stages of no contrast and partial contrast before perceiving the full deictic contrast. In support of the second hypothesis it was found that the language impaired Ss primarily used the same strategies in responding that non-language impaired children use, and exhibited the developmental errors previously observed in younger normal children. 5, 6, 16 The third hypothesis predicted that the language impaired Ss would comprehend the deictic terms in a predictable order based on the semantic complexity of the terms and according to acquisition in non-language impaired children. In support of this hypothesis it was found that Ss in Group E obtained significantly fewer errors on a predictable member in each pair of terms. However, there was no significant difference between the comprehension of each pair of deictic terms. $\mathrm{H}_{3}$ was thus only partially supported.

The findings of the present study indicated that the language impaired children tested were having problems on a semantic level. This suggests that the current academic interest in semantics should be extended to diagnostic testing and the planning of therapy. Furthermore, in view of the dearth of tests for the assessment of older language impaired children, tests involving the comprehension of deictic terms would be a useful part of diagnostic assessment.

\section{REFERENCES}

1. Campbell, P. and Wales, P. (1977): The Study of Language Acquisition, Chap. 13 in New Horizons in Linguistics, Lyons, J., (Ed.), Penguin Books Ltd., Harmondsworth, England.

2. Clark, E. V. (1971): On the Acquisition of the Meaning of Before and After. J. Verb. Learn. Verb'. Beh., 10, 266-275.

3. Clark, E. V. (1973a): What's in a Word? On the child's Acquisition of Semantics in His First Language in Cognitive 
Development and the Acquisition of Language, Moore, T. E., (Ed.), Academic Press, New York.

4. Clark, E. V. (1978): From Gesture to Word: On the Natural History of Deixis in Language Acquisition, Chap. 4 in Human Growth and Development. Wolfson College Lectures 1976 Bruner, J. S. and Garton, A. (Eds.), Oxford University Press, Oxford.

5. Clark, E. V. and Garnica, O. K. (1974): Is he Coming or Going? On the Acquisition of Deictic Verbs. J. Verb. Learn. Verb. Beh., 13, 556-572.

6. Clark, E. and Sengul, J. (1978): Strategies in the Acquisition of Deixis. J. Child. Lang., 5, 457-575.

7. De Villiers, P. A. and De Villiers, J. G. (1974): On This, That, and The Other. Nonegocentricsm in Very Young Children. $J$. Exp. Ch. Psych., 18, 438-447.

8. De Villiers, P. A. and De Villiers, J. G. (1978): The Development of Word Meaning. Chap. 5 in Language Acquisition, Harvard University Press, Cambridge.

9. Donaldson, M. and Balfour, G. (1968): Less is More. A Study of Language Comprehension in Children. Brit. J. Psychol., 59, $461-471$.

10. Lackner, J. R. (1976): A Development Study of Language Behaviour in Retarded Children. In Normal and Deficient Child Language. Morehead, D. M. and Morehead, A. E. (Eds.), University Park Press.

11. Macrae, A. J. (1976): Movement and Location in the Acquisition of Deictic Verbs. J. Child Lang., 3, 191-204.

12. Morehead, D. M. (1976): The Development of Base Syntax in Normal and Linguistically Deviant Children. In Normal and Deficient Child Language. Morehead, D. M. and Morehead, A. E. (Eds.), University Park Press, Baltimore.

13. Olson, D. R. (1977): The Contexts of Language Acquisition. Chap. 13 in Language Learning and Thoughts. Macnamara, J. (Ed.), Academic Press, New York.

14. Rees, N. S. (1978): Pragmatics of Language. Applications to Normal and Disordered Language Development. Chap. 5 in Bases of Language Intervention. Schiefelbusch, R. L. (Ed.), University Park Press. Baltimore.

15. Townsend, D. J. (1976): Do Children Interpret "Marked" Comparative Adjectives as their Opposites? J. Child Lang., 3, 385-396.

16. Webb, P. A. and Abrahamson, A. A. (1976): Stages of Egocentricsm in Children's Use of "This and That". A Different Point of View. J. Child Lang., 3, 349-367. 


\section{Aids for}

- the development of perception

- the acquisition of speech and language skills

- the improvement of motor co-ordination

\section{Plus}

- helpful texts for therapists

- educational toys, books and equipment

- records for auditory training

- catalogues on request

- large variety of tests available

\section{Stockists of}

- Learning to Listen

- Two sound lottos

- Full LDA range

\section{PLAY AND SCHOOLROOM}

8 Tyrwhitt Avenue, Rosebank

(adjoining the Constantia Cinema)

Telephones: 788-1304

P.O. Box 52137, Saxonwold, 2132

The South African Journal of Communication Disorders, Vol. 28, 1981 